\title{
PENGARUH LINGKUNGAN KELUARGA TERHADAP MINAT BERWIRAUSAHA SISWA SMA AISYIYAH I PALEMBANG
}

\author{
Nina Fitriana ${ }^{1)}$, Lusia Nargis ${ }^{2)}$, Agus Priyatno $^{3)}$ \\ 1,2)Dosen manajemen, Universitas Tridinanti Sumatera Selatan, Indonesia \\ 3)Mahasiswa manajemen, Universitas Tridinanti Sumatera Selatan, Indonesia \\ 1) nina_fitriana@univ-tridinanti.ac.id, 2) lusianargis@gmail.com
}

\begin{tabular}{l} 
INFORMASI ARTIKEL \\
\hline Submitted: \\
$01 / 12 / 2021$ \\
Revised: \\
15/12/2021 \\
Accepted: \\
25/12/2021 \\
Online-Published: \\
31/12/2021
\end{tabular}

\begin{abstract}
ABSTRAK
Penelitian iniditujukan untuk mengetahui pengaruh lingkungan keluarga terhadap minat berwirausaha siswa SMA Aisyiyah I Palembang.Jumlah responden dalam penelitian ini sebanyak 58 siswa. Hasil penelitian menunjukkan Nilai koefisien korelasi sebesar 0,683 artinya hubungan yang kuat dan bersifat positif (searah) antara lingkungan keluarga terhadap minat berwirausaha. Nilai koefisien determinasi sebesar 0,466 artinya $46,6 \%$ minat berwirausah dipengaruhi oleh lingkungan kerja dan sisanya 53,4\% dipengaruhi oleh variabel lain yang tidak diteliti dalam penelitian ini. Persamaan regresi didapatkan $\mathrm{Y}=15.927+1.147 \mathrm{X}$ yang artinya konstanta sebesar 15.927 menyatakan bahwa jika tidak ada nilai lingkungan keluarga maka nilai minat berwirausaha sebesar 15.927. Koofisien regresi X sebesar 1.147 menyatakan bahwa setiap penambahan satu satuan nilai lingkungan keluarga, maka nilai minat berwirausaha bertambah sebesar 1.147satuan.Uji t dengan nilai signifikansi $0,000<0,05$. Maka dapat disimpulkan bahwa terdapatpengaruh signifikan dari lingkungan keluarga terhadap minat berwirausaha.
\end{abstract}

\begin{abstract}
This research is aimed at knowing the influence of the family environment on the entrepreneurship interests of high school students Aisyiyah I Palembang. The number of respondents in this study was 58 students. The results showed a correlation coefficient value of 0.683 meaning a strong and positive relationship between the family environment and entrepreneurship interests. The coefficient of determination of 0.466 means that $46.6 \%$ of werwirausah interest is influenced by the work environment and the remaining $53.4 \%$ is influenced by other variables not studied in the study. The regression equation obtained $\mathrm{Y}=15.927+1,147 \mathrm{X}$ which means the constant of 15,927 states that if there is no value of the family environment then the value of entrepreneurship interest is 15,927 . The regression koofisien $X$ of 1,147 states that every addition of one unit of family environmental value, the value of entrepreneurship interest increases by 1,147 units. Test $t$ with significance value of $0.000<0.05$. So it can be concluded that there is a significant influence of the family environment on entrepreneurship interests.
\end{abstract}

Keywords :Interests, Entrepreneurship, Family Environment

\section{A. PENDAHULUAN}

Setiap manusia pasti memiliki kebutuhan-kebutuhan hidup yang harus terpenuhi demi kelangsungan hidupnya. Manusia memiliki kebutuhan yang beragam serta tidak pernah merasa puas dengan apa yang telah diperolehnya dan selalu ingin memperbaiki serta meningkatkan kualitas hidupnya. Untuk itu manusia dituntut berfikir bagaimana cara memenuhi kebutuhankebutuhan tersebut, baik itu bekerja ataupun berwirausaha.
Indonesia merupakan negara yang memiliki jumlah penduduk yang sangat banyak serta memiliki sumber kekayaan alam yang melimpah, ini membuat Indonesia pantas disebut sebagai negara yang kaya akan sumber dayanya, baik pada sumber daya alam maupun sumber daya manusia. Setiap tahun banyak siswa yang lulus dari sekolah negeri ataupun swasta dan banyak juga mahasiswa yang lulus dari perguruan tinggi negeri maupun swasta yangdapat 
meningkatkan kualitas sumber daya manusia di Indonesia.

Pengangguran itu bukanlah hasil sebuah pilihan untuk tidak bekerja, melainkan akibat dari semakin sulitnya mendapatkan pekerjaan, terutama di kota-kota besar.Ratarata lulusan dari sekolah maupun perguruan tinggi yang ketika lulus lebih menyiapkan diri untuk mencari pekerjaan, bukan untuk menciptakan lapangan pekerjaan. Caloncalon lulusan dari sekolah maupun perguruan tinggi lebih banyak menyiapkan diri untuk mengikuti seleksi penerimaan karyawan baru baik itu dari instansi pemerintah maupun dari perusahaan swasta, dari pada menyiapkan diri untuk membuka lapangan pekerjaan dengan berwirausaha. Oleh karena itu, para siswa dan mahasiswa perlu diarahkan dan didukung untuk tidak hanya berorientasi sebagai pencari kerja namun dapat dan siap menjadi pencipta pekerjaan atau berwirausaha.

Dewasa ini banyak masyarakat yang sulit menemukan lapangan pekerjaan. Hal tersebut terjadi karena semakin banyaknya jumlah penduduk di Indonesia yang tidak diimbangi dengan jumlah lapangan pekerjaan yang ada. Bagi mereka yang kurang mampu untuk melanjutkan keperguruan negri tinggi, hal tersebut tentunya menjadi salah satu kecemasan yang dirasakan oleh siswa yang akan segera lulus Sekolah Menengah Atas (SMA) maupun Sekolah Menengah Kejuruan (SMK).

$$
\text { Menurut Suryana (2013:2) }
$$

Kewirausahaan (entrepreneuship) adalah suatu disiplin ilmu yang mempelajari tentang nilai, kemampuan (ability), dan perilaku seseorang dalam menghadapi tantangan hidup dan cara memperoleh peluang dengan berbagai resiko yang mungkin dihadapinya. Kewirausahaan merupakan suatu disiplin ilmu tersendiri, memiliki proses sistematis, dan dapat diterapkan dalam bentuk penerapan kreatifitas dan keinovasian.

Berwirausaha tidak hanya dapat dilakukan bagi mereka yang mempunyai modal besar, akan tetapi berwirausaha juga dapat dilakukan bagi mereka yang mempunyai modal terbatas. Tidak semua jenis usaha berskala besar. Pada umumnya, suatu usaha yang besar juga diawali oleh usaha yang kecil. Usaha kecil tersebut kemudian dapat bertumbuh menjadi sesuatu usaha yang besar.

Dari suatu pengalaman yang didapat siswa baik itu melalui keluarga, teman sebaya maupun dilingkungan sekitarnya, minat untuk berwirausaha akan timbul dengan sendirinya jika siswa mempunyai ketertarikan untuk berwirausaha, misalnya pengaruh dari lingkungan keluarga yang mempunyai peranan penting dalam memberi pengalaman kepada siswa untuk belajar berwirausaha, serta juga bisa melalui informasi yang ia dapatkan dikehidupan sehari-harinya.

Menurut Mohammad Ali dan Mohammad Asrori (2010:34) paling penting dilakukan oleh keluarga atau orang tua adalah memberi pengalaman kepada anak dalam berbagai bidang kehidupan sehingga anak memiliki informasi yang banyak (www.perpuskampus.com/pengertianlingkungan-keluargaf).

Pergeseran pemikiran siswa akan melihat peluang kerja yang semakin menipis dikarenakan persaingan yang semakin ketat menuntut mereka untuk berfikir mencari pendapatan dengan cara selain bekerja yaitu dengan berwirausaha. Selain dapat memenuhi kebutuhan setiap siswa, berwirausaha secara tidak langsung juga dapat menyerap jumlah pengangguran yang ada.

Seorang wirausahawan haruslah mempunyai daya kreatifitas dan inovasi yang baru dalam menentukan usaha yang akan dijalankannya agar usaha tersebut terlihat lebih menarik serta berbeda dari pada pelaku usaha lainnya. Seorang wirausahawan yang kreatif akan selalu memikirkan hal-hal unik yang belum pernah terfikirkan sebelumnya oleh pelaku usaha lainnya, serta selalu memperkenalkan tentang pembaruan yang belum ada sebelumnya.

SMA Aisiyah I Palembang adalah Sekolah Menengah Atas yang berada di Kota Palembang. Denganjumlahsiswasebanyak 138 orang .Dari jumlah siswa tersebut, siswa cenderung ingin melanjutkan pendidikan pada perguruan tinggi di Palembang. Sedangkan bagi siswa yang kurang mampu perekonomiannya, mereka cenderung ingin melamar kerja pada perusahaan-perusahaan yang sedang membutuhkan tenaga kerja lulusan SMA. 
Rendahnya minat untuk berwirausaha siswa adalah karena mereka takut untuk mencoba sesuatu hal yang baru, serta mereka takut akan kegagalan pada usaha yang akan mereka jalankan. Akan tetapi, dukungan serta motivasi secara terus menerus yang diberikan keluarga kepada siswa dapat merubah pemikiran mereka pada kegagalan usaha yang akan mereka jalankan.

\section{PerumusanMasalah}

Berdasarkan uraian latar belakang diatas, maka rumusan masalah dalam penelitian tersebut adalah adakah pengaruh lingkungan keluarga terhadap minat berwirausaha siswa SMA Aisyiyah I Palembang. Adapun tujuan dari penelitian ini adalah untuk mengetahui pengaruh lingkungan keluarga terhadap minat berwirausahasiswa SMA Aisyiah I Palembang.Hasil penelitian ini diharapkan dapat memberikan hal positif terhadap siswa dalam meningkatkan minat berwirausaha

Lingkungan merupakan segala sesuatu yang ada di sekitar manusia, serta mempengaruhi segala sesuatu yang ada di dalam kehidupan manusia. Menurut $M$. Dalyono (2009:129) mengatakan bahwa Lingkungan itu sebenarnya mencakup segala material dan stimulus di dalam dan di luar diri individu, baik bersifat fisiologis, psikologis, maupun sosial kultural.

Sedangkan keluarga merupakan suatu organisasi terkecil di dalam masyarakat yang terdiri dari beberapa individu yang berkumpul dan tinggal pada suatu tempat yang sama di bawah atap dalam keadaan saling ketergantungan. Menurut Nugroho J. Setiadi (2003:199-200) mengatakan bahwa :

1. keluarga (family) adalah kelompok yang terdiri dari dua atau lebih orang yang berhubungan melalui darah, perkawinan, atau adopsi, dan tinggal bersama.

2. Keluarga inti (nuclear family) adalah kelompok langsung yang terdiri dari ayah, ibu, dan anak yang tinggal bersama.

3. Keluarga besar (extended family) mencakupi keluarga inti, ditambah keluarga lain, seperti kakek, nenek, paman, dan bibi, sepupu, dan kerabat karena perkawinan.
Selanjutnya menurut Menurut Khairuddin (2008:2) mengatakan bahwa keluarga adalah:

1. Keluarga merupakan kelompok sosial kecil yang umumnya terdiri dariayah, ibu, dan anak.

2. Hubungan sosial diantara anggota keluarga relatif tetap dan didasarkanatas ikatan darah, perkawinan dan atau adobsi

3. Hubungan antar keluarga dijiwai oleh suasana kasih sayang dan rasa tanggung jawab

4. Fungsi keluarga ialah merawat, memelihara, dan melindungi anak dalamrangka sosialisasinya agar mereka mampu mengendalikan diri danberjiwa sosial.

Berdasarkan beberapa uraian di atas dapat disimpulkan bahwa lingkungan keluarga adalah segala sesuatu yang berada dalam kelompok sosial kecil yang berfungsi untuk melindungi setiap anggotanya yang terdiri dari ayah, ibu dan anak yang memiliki hubungan darah serta rasa kasih sayang diantara mereka.

\section{Fungsi Lingkungan Keluarga}

Selain mempunyai rasa ketergantungan satu sama lain, Menurut Arief Rahman (2009:200) keluarga memiliki fungsi sebagai berikut:

1. Fungsi Proteksi

Keluarga harus memberikan perlindungan, perawatan,serta menjaga dari setiap gangguan yang dapat mengancam keselamatananggota keluarganya.

2. Fungsi Rekreasi

Keluarga harus memberikan dan menciptakan rasa damai,dan tentram sehingga lingkungan keluarga memberikan saranahiburan bagi anak

3. Fungsi Inisiasi

Keluarga harus mengenalkan kepada anak tentang hal -halyang berada disekitar lingkungannya, seperti nama hewan, nama kelurgayang lain, saudara, dan tetanga agar anak mengenal lingkungansekitarnya.

4. Fungsi Sosialisasi

Anak harus diberikan pendidikan mengenai adatistiadat, budaya yang diterapkan di lingkungan yang ditempati agar anakdapat hidup baik dengan masyarakat setempat. 


\section{Fungsi Edukasi}

Anak harus diberi pendidikan sejak dini baik yang bersifatpengetahuan maupun yang bersifat budaya. Agar anak bisa tumbuhmenjadi anak yang cerdas dan bermoral.

Sedangkan menurut Berns dalam Sri Lestari (2012:22) keluarga memiliki lima fungsi dasar, yaitu

1. Reproduksi

Keluarga memiliki tugas untuk mempertahankan populasi yang ada di dalam masyarakat.

2. Sosialisasi/edukasi

Keluarga menjadi sarana untuk transmisi nilai, keyakinan, sikap, pengetahuan keterampilan, dan teknik dari generasi sebelumnya ke generasi yang lebih mudah.

3. Penugasan peran sosial

Keluarga memberikan identitas pada para anggotanya seperti ras, etnik, religi, sosial ekonomi, dan peran gender.

4. Dukungan ekonomi

Keluarga menyediakan tempat berlindung, makanan, dan jaminan kehidupan.

5. Dukungan emosi/pemeliharaan

Keluarga memberikan pengalaman interaksi sosial yang pertama bagi anak. Interaksi yang terjadi bersifat mendalam, mengasuh, dan berdaya tahan sehingga memberikan rasa aman pada anak.

Dalam perspektif perkembangan fungsi paling penting dari keluarga adalah melakukan perawatan dan sosialisasi pada anak. Sosialisasi merupakan proses yang ditempuh anak untuk memperoleh keyakinan, nilai-nilai dan perilaku yang dianggap perlu dan pantas oleh anggota keluarga dewasa, terutama orang tua. Keluarga memang bukan satu-satunya lembaga yang melakukan peran sosialisasi, melainkan keluarga merupakan tempat pertama bagi anak dalam menjalankan kehidupannya. Oleh karena berbagai peristiwa, pada awal tahun kehidupan anak sangat berpengaruh pada perkembangan sosial, emosi, dan intelektual anak, maka keluarga harus dipandang sebagai instrumen sosialisasi utama.

Berdasarkan beberapa pendapat di atas dapat kita simpulkan bahwa selain berfungsi melindungi setiap anggotanya, keluarga merupakan tempat di mana anak mulai mengenal lingkungan sekitarnya, belajar mengetahui hal-hal dasar yang belum pernah ia ketahui sebelumnya, serta membentuk atau menemukan jati diri yang terdapat di dalam dirinya.

Selanjutnya menurut Sri Lestari (2012:23) mengatakan bahwa keberfungsian keluarga dapat dinilai dari tingkat kelentingan keluarga (resiliency) atau kekukuhan (strength) keluarga dalam menghadapi berbagai masalah.

1. Kelentingan keluarga

Komunikasi yang baik merupakan faktor yang penting bagi keberfungsian dan kelentingan keluarga. Komunnikasi mencakup transmisi keyakinan, pertukaran informasi, pengungkapan perasaan, dan proses penyelesaian masalah. Tiga aspek komunikasi yang menjadi kunci bagi kelentingan keluarga adalah :

a. Kemampuan memperjelas pesan yang memungkinkan anggota keluarga untuk memperjelas situasi krisis.

b. Kemampuan untuk mengungkapkan perasaan yang memungkinkan anggota keluarga untuk berbagi, saling berempati, berinteraksi secara menyenangkan, dan bertanggung jawab terhadap masingmasing perasaan dan perilakunya.

c. Kesediaan berkolaborasi dalam menyelesaikan masalah sehingga yang berat sama dipikul dan yang ringan sama dijinjing.

2. Kekukuhan keluarga Terdapat enam karakteristik keluarga yang kukuh adalah sebagai berikut :

1. Memiliki komitmen

2. Terdapat kesediaan untuk mengungkapkan apresiasi

3. Terdapat waktu untuk kumpul bersama

4. Mengembangkan spiritualitas

5. Menyelesaikan konflik serta mnghadapi tekanan dan krisis dengan efektif

6. Memiliki ritme

\section{Teori Sistem Keluarga}

Menurut teori sistem, keluarga dianggap sebagai sebuah sistem yang memiliki bagianbagian yang berhubungan dan saling berkaitan, Randal D.Day dalam Sri Lestari (2012:26-30) mengungkapkan bahwa 
keluarga sebagai sebuah sistem memiliki karakteristik sebagai berikut :

1. Keseluruhan (The family as a whole) Memahami keluarga tidak dapat dilakukan tanpa memahaminya sebagai sebuah keseluruhan. Persoalan individu tidak hanya dilihat terbatas pada individu yang bersangkutan. Dalam pendekatan keluarga sebagai sistem, perhatian utamanya justru diberikan pada bagaimana kehidupan keluarga, baru kemudian memberikan fokus pada individu.

2. Struktur (underlying structurs)

Suatu kehidupan keluarga berlangsung berdasarkan suatu struktur, misalnya pola interaksi antaranggota keluarga yang menentukan apa yang terjadi di dalam keluarga,

3. Tujuan (families have goals)

Setiap keluarga memiliki tujuan yang ingin mereka raih. Efektivitas pencapaian tujuan suatu keluarga tergantung seberapa besar sumbangan masing-masing anggota keluarga terhadap pencapaian tujuan.

4. Keseimbangan (equilibrium)

Dalam rangka meraih tujuannya keluarga akan menghadapi situasi dan kondisi di luar dirinya yang berubah dan berkembang. Keluarga akan senantiasa melakukan adaptasi, menyesuaikan dengan perubahan dan menanggapi situasi dan kondisi yang dihadapi. Keluarga akan senantiasa mencapai tujuannya dengan menjaga kehidupannya agar tetap seimbang.

5. Kelembaman (morphostatis)

Selain berusaha mencapai keseimbangan dengan berbagai perubahan situasi dan kondisi, keluarga juga mempertahankan aturan dan menjaga kelangsungan kehidupan sehari-hari agar tetap berlangsung dengan baik.

6. Batas-batas (boundaries)

Sebagai sebuah sistem yang terbuka, keluarga memiliki batas-batas terluar yang bersifat mudah tembus (permeable). Batas-batas dari suatu keluarga dapat dilihat dari aturan-aturan yang dibangun di dalam keluarga, misalnya apa saja yang boleh atau tidak boleh dilakukan oleh anggota keluarga, siapa saja yang boleh datang dan pergi tanpa batasan. Apabila batas-batasnya mudah tembus berarti keluarga memiliki batas-batas yang tidak rapat. Pada kenyataannya ada keluarga yang batas-batasnya sangat mudah tembus seperti saringan, sementara keluarga yang lain sangat protektif dan sulit ditembus seperti dinding-dinding istana.

7. Subsistem

Di dalam sistem keluarga terdapat unitunit subsistem, misalnya subsistem pasangan suami istri, subsistem relasi orang tua dan anak, subsistem peran orang tua. Salah satu tugas utama dari subsistem keluarga adalah menjaga batas-batas keluarga. Konsep tentang subsistem ini membantu kita untuk memahami bahwa keluarga bukan hanya terdiri dari individu-individu yang menjadi anggota keluarga, melainkan terdapat berbagai interaksi yang membentuk subsistem keluarga. Proses saling mempengaruhi terjadi antar individu, subsistem, atau antara subsistem dan individu.

8. Equifinality dan equipotentiality

Secara sederhana gagasan tentang equifinality berarti bahwa berbagai permulaan dapat membawa pada hasil akhir yang sama, sementara suatu permulaan yang sama dapat pula membawa pada hasil akhir yang berbeda. Sebagai contoh, berbagai kajian tentang interaksi orang tua-anak memperlihatkan bahwa keterlibatan yang berlebihan (overinvolvement) dari orang tua dapat menyebabkan hasil yang berbeda. Sikap orang tua yang sangat tanggap (overresponsive) dapat menyebabkan sebagian anak menjadi sangat berprestasi ( overachieve). Dan dapat pula menyebabkan sebagian anak yang lain menjadi kurang berprestasi (underachieve). Contoh lainnya adalah anak-anak yang memiliki orang tua pecandu alkohol dapat menyebabkan anak ikut mencandu alkohol atau berskap anti alkohol. Adapun equipotentiality berarti bahwa suatu sebab dapat menghasilkan suatu akibat sangat terkait dengan proses apa yang berjalan mengikuti sebab tersebut.

Berdasarkan uraian di atas dapat disimpulkan bahwa keluarga sebagai sistem harus dipandang sebagai keseluruhan, 
mempunyai struktur penopang, tujuan, menjaga keseimbangan, mempunyai kelembaman, batas-batas, subsistem, dan mengikuti prinsip equifinalty dan equipotentiality.

Minat merupakan dorongan, keinginan, atau ketertarikan dalam diri seseorang pada objek tertentu, setiap individu pastinya mempunyai minat yang bisa saja atau bahkan mungkin berbeda dengan individu lainnya. Biasanya minat diawali oleh perasaan senang dan sikap positif. Menurut Slameto (2010:180) mengatakan bahwa minat adalah suatu rasa lebih suka dan rasa ketertarikan pada suatu hal atau aktifitas tanpa ada yang menyuruh. Selanjutnya menurut Crow and Crow dalam Djali (2008:121) mengatakan bahwa minat berhubungan dengan gaya gerak yang mendorong seseorang untuk menghadapi atau berurusan dengan orang, benda, kegiatan, pengalaman yang diransang oleh kegiatan itu sendiri. Sedangkan menurut Syah (2007:151) mendefinisikan minat (interest) sebagai kecenderungan dan kegairahan yang tinggi atau keinginan besar terhadap sesuatu .

Berdasarkan pemaparan oleh para ahli diatas mengenai minat, dapat disimpulkan bahwa pada dasarnya minat adalah suatu ketertarikan seseorang terhadap suatu hal yang ia tunjukkan dengan memberikan perhatian yang lebih besar terhadap hal tersebut.

Wirausaha adalah seorang yang mampu mengelola sumber-sumber daya dalam menciptakan suatu peluang serta berani mengambil segala resikodalam menciptakan suatu peluang usaha dan usaha baru. Menurut Kamus Besar Bahasa Indonesia (KBBI) pengertian wirausaha sama dengan wiraswasta, yaitu orang yang pandai atau berbakat mengenali produk baru, menentukan cara produksi baru, menyusun operasi untuk pengadaan produk baru, memasarkannya, serta mengatur permodalan operasinya.

Ciri-ciri umum seorang pelaku usaha biasanya dapat dilihat dari berbagai faktor kepribadian, misalnya jiwa, watak, dan perilaku seseorang. Menurut Suryana (2013:22) ciri-ciri kewirausahaan tersebut dapat dilihat dari berbagai indikator sebagai berikut :
1. Penuh percaya diri, indikatornya adalah penuh keyakinan, optimis, berkomitmen, disiplin, dan bertanggung jawab

2. Memiliki inisiatif, indikatornya adalah penuh energi, cekatan dalam bertindak, dan aktif.

3. Memiliki motif berprestasi, indikatornya adalah berorientasi pada hasil dan wawasan ke depan.

4. Memiliki jiwa kepemimpinan, indikatornya adalah berani tampil beda, dapat dipercaya, dan tangguh dalam bertindak.

5. Berani mengambil resiko dengan penuh perhitungan, oleh karena itu menyukai tantangan.

Didalam berwirausaha setiap pelaku usaha pastinya mempunyai berbagai macam karakteristik berbeda-beda yang harus mereka terapkan dalam menjalankan suatu usahanya tersebut. Menurut M. Scarborough dan Thomas W. Zimmerer dalam Suryana (2013:23) mengatakan bahwa terdapat delapan karakteristik kewirausahaan yang meliputi hal-hal sebagai berikut :

1. Rasa tanggung jawab (desire for responsibility)

Memiliki rasa tanggung jawab atas usahausaha yang dilakukannya. Seseorang yang mempunyai rasa tanggung jawab akan selalu berkomitmen dan waswas diri

2. Memilih resiko yang moderat (preference for moderate risk)

Lebih memilih resiko yang moderat, artinya selalu menghindari resiko, baik yang terlalu rendah maupun yang terlalu tinggi.

3. Percaya diri terhadap kemampuan sendiri (confidence in their ability to success)

Memiliki kepercayaan diri atas kemampuan yang dimilikinya untuk memperoleh kesuksesan.

4. Menghendaki umpan balik segera (desire for immediate feedback)

Selalu menghendaki adanya umpan balik dengan segera, ingin cepat berhasil.

5. Semangat dan kerja keras (high level of energy)

Memiliki semangat dan kerja keras untuk mewujudkan keinginannya demi masa depan yang lebih baik.

6. Berorientasi ke depan (furure orientation) 
Berorientasi masa depan dan memiliki perspektif dan wawasan jauh ke depan.

7. Memiliki keterampilan berorganisasi (skill at organizing)

Memiliki keterampilan dalam mengorganisasikan sumber daya untuk menciptakan nilai tambah.

8. Menghargai prestasi (value of arcievement over money)

Lebih menghargai prestasi dari pada uang.

Seorang wirausahawan tidak pernah melakukan suatu pekerjaan atau pelaksanaan apa yang telah direncanakan sebelumnya secara setengah-setengah, karena seorang wirausahawan merupakan seorang yang rajin, ulet, dan pantang menyerah. Ia berani menghadapi segala resiko yang bakal terjadi karena ia telah memperhitungkan apa yang telah direncanakan sebelumnya dengan matang.

Selanjutnya menurut Arthur Kuriloff dan John M. Mempil dalam Suryana (2013:23-24) mengemukakan karakteristik kewirausahaan dalam bentuk nilai-nilai dan perilaku kewirausahaan adalah seperti yang diuraikan pada tabel 1

Tabel 1. Nilai-Nilai Dan Perilaku

Kewirausahaan

\begin{tabular}{|c|c|}
\hline Nilai-Nilai & Penlaku \\
\hline Komitmen & Menyelesaikan tugas hingga selesai \\
\hline Risiko Moderat & $\begin{array}{l}\text { Tidak melakukan tindakan spekulatif, melainkan } \\
\text { berdasakan pada pehitungan yang matang }\end{array}$ \\
\hline Melihat peluang & Memanfaatkan peluang yang ada sebaik mungkin \\
\hline Objhtivitas & $\begin{array}{l}\text { Melakukan pengamatan secara nyata untuk } \\
\text { memperoleh kejelasan }\end{array}$ \\
\hline Umpan baik & $\begin{array}{l}\text { Menganalisis data kinerja waktu untuk memandu } \\
\text { kegiatan }\end{array}$ \\
\hline Optimisne & $\begin{array}{l}\text { Menurjulkan kepercayaan diri yang besar } \\
\text { walaupum berada dalam situasi berat }\end{array}$ \\
\hline Uang & $\begin{array}{l}\text { Melihat uang sebagai suatu sumber daya, bukan } \\
\text { tujuan akhir }\end{array}$ \\
\hline Manajemen proaktif & $\begin{array}{l}\text { Mengelola berdasarkan pada perencanaan masa } \\
\text { depan }\end{array}$ \\
\hline
\end{tabular}

Pada era di mana telepon seluler (handphone) sebagai alat komunikasi belum secanggih dan berkembang pesat seperti saat ini, kita pastinya mengenal sebuah usaha warung telekomunikasi (wartel) yang menawarkan jasa komunikasi untuk berhubungan antar individu dari jarak jauh. Baik itu antar daerah, provinsi, kota dan lain sebagainya.

Menurut Ismail Solihin (2007:2-3) para pengusaha dapat dikelompokkan ke dalam tiga kelompok, yaitu:

\section{Pengusaha Pro Aktif}

Pengusaha yang termasuk ke dalam kelompok ini adalah pengusaha yang mengantisipasi terjadinya perubahan dan melakukan berbagai langkah untuk memanfaatkan peluang usaha sehingga dapat memperoleh keuntungan.

2. Pengusaha reaktif

Pengusaha yang termasuk ke dalam kelompok ini adalah para pengusaha yang melakukan tanggapan segera terhadap perubahan lingkungan usaha, setelah perubahan lingkungan usaha tersebut terjadi.

3. Pengusaha pasif

Pengusaha yang termasuk ke dalam kelompok ini adalah para pengusaha yang menjalankan bisnis apa adanya atau menjalankan bisnis menurut cara-cara lama tanpa mempertimbangkan secara serius perubahan lingkungan usaha yang sedang terjadi.

Ilustrasi-ilustrasi di atas mengajarkan kita betapa pentingnya dalam menyusun sebuah rencana usaha, agar kita siap dalam menghadapi perubahan lingkungan usaha yang semakin berkembang dengan cepatnya. Selanjutnya,Berdasarkan perannya Roopke dalam Suryana (2013:58) mengelompokan kewirausahaan sebagai berikut:

1. Wirausahawan rutin

Wirausahawan yang dalam melakukan kegiatan sehari-harinya cenderung berfokus pada pemecahan masalah dan perbaikan standar prestasi tradisional. Fungsi wirausahawan rutin adalah mengadakan perbaikan terhadap standar tradisional, bukan penyusunan dan pengalokasian sumber-sumber. Wirausahawan ini berusaha untuk menghasilkan barang, pasar, dan teknologi. Misalnya seorang pegawai atau manajer. Wirausahawan rutin dibayar dalam bentuk gaji.

2. Wirausahawan arbitrase

Wirausahawan yang selalu mencari peluang melalui kegiatan penemuan (pengetahuan) dan pemanfaatan (pembukaan). Misalnya, bila tidak terjadi ekuilibrium dalam penawaran dan permintaan pasar, ia akan membeli dengan murah dan menjualnya dengan mahal. 
Kegiatan kewirausahaan arbitrase tidak perlu melibatkan pembuatan barang dan penyerapan dana pribadi wirausahawan. Kegiatannya melibatkan spekulasi dalam memanfaatkan perbedaan harga jual dan beli.

3. Wirausahawan inovatif

Wirausahawan dinamis yang menghasilkan ide dan kreasi baru yang berbeda. Ia merupakan promotor, tidak saja dalam memperkenalkan teknik dan produk baru, tetapi juga dalam pasar dan sumber pengadaan, peningkatan teknik menejemen, dan metode distribusi baru. Ia mengadakan proses dinamis pada produk, hasil, sumber pengadaan, dan organisasi yang baru.

Selain karena kebutuhan, tak banyak para pelaku usaha yang membuka usahanya hanya untuk belajar menjadi seorang wirausahawan atau bahkan hanya sekedar mengisi waktu luang serta juga menjadikan sebuah hoby yang mereka wujudkan menjadi sebuah usaha yang dapat mengasilkan pendapatan. Menurut Thomas Zimmere dalam Suyana (2013:58) mengelompokan wirausahawan berdasarkan pada profilnya menjadi empat kelompok sebagai berikut.

1. Part-time entrepreneur, yaitu wirausahawan yang hanya setengah waktu melakukan usaha, biasanya sebagai hoby. Kegiatan usahanya hanya bersifat sampingan

2. Home-based new ventures, yaitu usaha yang dirintis dari rumah atau tempat tinggal

3. Family-owned busines, yaitu usaha yang dilakukan atau dimiliki oleh beberapa anggota keluarga atau secara turun temurun.

4. Copreneurs, yaitu usaha yang dilakukan oleh dua orang wirausahawan yang bekerja sama sebagai pemilik dan menjalankan usahanya bersama-sama

Berdasarkan pendapat di atas dapat kita simpulkan bahwa sebuah usaha dapat timbul bukan hanya karena niat secara langsung dari pelaku usaha, akan tetapi dapat juga timbul secara tidak langsung dari cara kita mengambil sebuah peluang usaha tersebut. Misalnya dari hoby atau keadaan tempat tinggal yang memunculkan sebuah ide kita untuk berwirausaha.

\section{Fungsi Dan Peran Wirausahawan}

Selain memperoleh penghasilan dan dapat memenuhi berbagai kebutuhan sehariharinya. Secara tidak langsung, telah banyak para wirausahawan yang mampu menyerap pengangguran yang ada. Selanjutnya, Suryana (2013:59-60) mengatakan ada dua fungsi dan peran wirausahawan dalam perekonomian, yaitu :

\section{Fungsi Makro}

Secara makro, wirausahawan berperan dalam ekonomi nasional sebagai penggerak, pengendali, dan pemacu perekonomian suatu bangsa. Para wirausahawan berfungsi menciptakan investasi baru, pembentuk modal baru, menghasilkan lapangan kerja baru, menciptakan produktifitas, meningkatkan ekspor, mendorong pertumbuhan ekonomi, mengurangi kesenjangan sosial, dan meningkatkan kesejahteraan.

Sementara itu, peran wirausahawan melalui usaha-usaha kecil adalah:

Pertama, usaha kecil dapat memperkokoh perekonomian nasional melalui berbagai keterkaitan usaha, sebagai fungsi pemasok, fungsi produksi, fungsi penyalur, dan fungsi pemasaran bagi hasil produksi industri besar

Kedua, usaha kecil dapat meningkatkan efisiensi ekonomi, khususnya dalam menyerap sumber daya yang ada. Usaha kecil sangat fleksibel karena dapat menyerap tenaga kerja dan sumber daya lokal serta meningkatkan sumber daya manusia agar dapat menjadi wirausahawan yang tangguh.

Ketiga, usaha kecil dipandang sebagai sarana pendistribusian pendapatan nasional, alat pemerataan berusaha dan alat pendistribusian pendapatan karena jumlahnya tersebar, baik di perkotaan maupun di pedesaan.

2. Fungsi mikro

Secara mikro, fungsi wirausahawan dalam perusahaan adalah menanggung resiko ketidakpastian, mengkombinasikan sumber-sumber ke dalam cara yang baru dan berbeda, menciptakan nilai tambah, 
menciptakan usaha-usaha baru, dan pencipta peluang-peluang baru.

Adapun kerangka berfikir dapat digambarkan sebagai berikut:

\section{Gambar 1 Kerangka Berfikir}

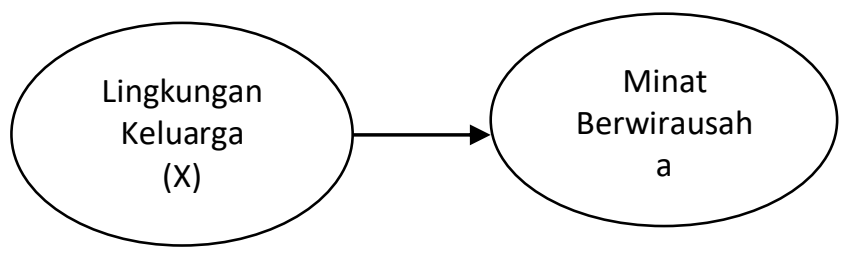

Menurut Sugiyono (2013:99) Hipotesis merupakan jawaban sementara terhadap rumusan masalah penelitian, di mana rumusan masalah penelitian telah dinyatakan dalam bentuk kalimat pertanyaan. Adapun hipotesis dalam penelitian ini adalah diduga ada pengaruh lingkungan keluarga terhadap minat berwirausaha siswa SMA Aisyiyah I Palembang.

\section{B. METODE PENELITIAN}

Penelitian ini dilakukan pada siswa SMA Aisyiyah I Palembang yang berada di jalan Balayudha km 4.5 kota Palembang, Sumatra Selatan 30128. Waktu penelitian dilakukan selama kurang lebih lima bulan. Populasi dalam penelitian ini adalah siswa kelas XII SMA Aisyiyah I Palembang yang berjumlah 138 orang

Menurut Sugiyono (2013:81) "Sampel yaitu bagian dari jumlah dan karakteristik yang dimiliki oleh populasi tersebut. Sampel dilakukan karena keterbatasan peneliti dalam melakukan penelitian baik dari segi dana, waktu, tenaga, dan jumlah populasi yang sangat banyak".

Untuk menentukan jumlah sampel yang ditarik dengan menggunakan rumus Slovin. Sampel diambil sebanyak 58 siswa kelas XII Sma Aisyiyah I Palembang sebagai sampel penelitian.

Menurut Sugiyono (2010:118) Teknik sampling merupakan teknik pengambilan sampel untuk menentukan sampel yang akan digunakan dalam penelitian.

Dalam penelitian ini, peneliti menggunakan teknik sampling acak sederhana (simple random sampling). Simple random sampling merupakan pengambilan sampel dari populasi secara acak tanpa memperhatikan strata yang ada dalam populasi dan setiap anggota populasi memiliki kesempatan yang sama untuk dijadikan sampel.

Rancangan penelitian yang digunakan peneliti dalam penelitian ini yaitu menggunakan menggunakan Deskriptif Kuantitatif. Dalam penelitian ini peneliti menggunakan 2 variabel yaitu : 1 variabel independen (variabel bebas) dan 1 variabel dependen (variabel terikat).

Variabel X: Lingkungan Keluarga

Variabel Y : Minat Berwirausaha

\section{Kisi-kisi Instrumental}

Tabel 2 Kisi-kisi Instrumental Lingkungan

Keluarga (X)

\begin{tabular}{|l|l|l|c|}
\hline No & Indikator & Sub Indikator & Pernyataan \\
\hline 1 & Proteksi & $\begin{array}{l}- \text { Perlindungan } \\
- \text { Perawatan } \\
- \text { Menjaga }\end{array}$ & $1-3$ \\
\hline 2 & Rekreasi & $\begin{array}{l}- \text { Damai } \\
- \text { Tentram } \\
- \text { Sarana Hiburan }\end{array}$ & \\
\hline 3 & Inisiasi & $\begin{array}{l}- \text { Pengenalan } \\
\text { terhadap hal baru }\end{array}$ & $7-6$ \\
\hline 4 & Sosialisasi & - Pendidikan & 8 \\
\hline 5 & Edukasi & $\begin{array}{l}- \text { Pendidikan } \\
- \text { Pengetahuan }\end{array}$ & $9-10$ \\
& & & \\
\hline
\end{tabular}

Sumber : Arief Rahman (2009:200)

Tabel 3 Kisi-kisi Instrumental Minat

Berwirausaha (Y)

\begin{tabular}{|c|c|c|c|}
\hline No & Indikator & Sub Indikator & Pernyataan \\
\hline 1 & Percaya Diri & $\begin{array}{ll}\text { - } & \text { Keyakinan } \\
\text { - } & \text { Optimis } \\
\text { - } & \text { Berkomitmen } \\
\text { - } & \text { Disiplin } \\
\text { - } & \text { Bertanggung } \\
& \text { Jawab }\end{array}$ & $1-5$ \\
\hline 2 & Inisiatif & $\begin{array}{ll} & \text { Penuh Energi } \\
\text { - } & \text { Cekatan } \\
\text { - } & \text { Aktif } \\
\end{array}$ & $6-8$ \\
\hline 3 & $\begin{array}{l}\text { Motif } \\
\text { Berprestasi }\end{array}$ & $\begin{array}{ll} & \text { Berorientasi } \\
\text { - } & \text { Mempunyai } \\
& \text { Wawasan } \\
\end{array}$ & $9-10$ \\
\hline 4 & $\begin{array}{l}\text { Jiwa } \\
\text { Kepemimpinan }\end{array}$ & $\begin{array}{l}\text { - } \text { Tampil Beda } \\
\text { - Dipercaya } \\
\text { - } \text { Tangguh }\end{array}$ & $11-13$ \\
\hline 5 & $\begin{array}{l}\text { Berani } \\
\text { Mengambil } \\
\text { Resiko }\end{array}$ & $\begin{array}{ll}\text { - } & \text { Penuh } \\
& \text { Perhitungan } \\
\text { - } & \text { Menyukai } \\
& \text { Tantangan }\end{array}$ & $14-15$ \\
\hline
\end{tabular}

Sumber : Suryana (2013:22) 
Untuk melakukan pengumpulan data digunakan teknik angket dengan menggunakan skala likert. Data yang dihubungkan dari tiap siswa ditampung pada instrumen pengumpul data berupa kuesioner, dimana isiannya diambil dari komponen diatas dengan skala pengukuran skala likert.Skala likert adalah skala yang dapat dipergunakan untuk mengukur sikap, pendapat, dan persepsi sesorang atau sekelompok orang mengenai suatu gejala atau fenomena yang terjadi. Dalam skala likert variabel yang diukur dalam penelitian ini adalah variabel lingkungan keluarga, dan minat berwirausaha.

Pengujian instrumen perlu dilakukan sebelum melakukan penelitian. Hal ini dimaksudkan agar instrumen yang akan digunakan dalam mengukur variabel mamiliki validitas dan reliabilitas sesuai dengan ketentuan.

Sebelum melakukan analisis data, instrumen diuji validitas dahulu. Menurut Sugiyono (2013:168) menyatakan bahwa suatu hasil penelitian dikatakan valid jika adanya kesesuaian antara data yang terkumpul dengan data objek yang diteliti. Untuk uji validitas peneliti menggunakan korelasi product moment dengan bantuan program SPSS Windows 22.0.

Untuk menentukan instrumen valid atau tidak adalah dengan ketentuan sebagai berikut :

a. Jika $r_{\text {hitung }}>r_{\text {tabel }}$ dengan taraf signifikansi $5 \%$, maka instrumen tersebut dikatakan valid.

b. Jika $r_{\text {hitung }}<r_{\text {tabel }}$ dengan taraf signifikansi $5 \%$, maka instrumen tersebut dikatakan tidak valid.

Realibilitas menunjukkan instrumen pada tingkat keterandalan tertentu. Reliabel artinya dapat dipercaya, jadi dapat diandalkan. Sebagaimana yang dikemukakan Sugiyono (2013:168) instrumen yang reliabilitas jika digunakan beberapa kali untuk mengukur objek yang sama akan mendapatkan data yang sama.

Uji ini dilakukan dengan cara membandingkan angka nilai Cronbach Alpha dengan ketentuan jika nilai Cronbach Alphayang didapatkan dari hasil perhitungan SPSS 22.0 lebih besar dari 0,05 maka instrumen tersebut dinyatakan reliabel, dan sebaliknya jika Cronbach Alpha lebih kecil dari 0,05 maka instrumen tidak reliabel.

\section{Uji Normalitas Data}

Menurut Imam Ghozali (2011:160) tujuan dari normalitas adalah sebagai berikut:

1 Uji normalitas bertujuan untuk mengetahui apakah dalam variabel penggangu atau residual memiliki distribusi normal.

2 Uji normalitas data dalam penelitian ini akan menggunakan pengujian Kolmogorof Smirnov satu arah. Pengambilan kesimpulan untuk menentukan apakah suatu data mengikuti distribusi normal atau tidak adalah dengan menilai nilai signfikan

Hipotesis

- $\mathrm{H0}: \mathrm{B} 1=0$ (tidak ada pengaruh antara lingkungan keluarga terhadap minat berwirausaha siswa SMA Aisiyah I Palembang).

- H0 : B1 $\neq 0$ (ada pengaruh antara lingkungan keluarga terhadap minat berwirausahasiswa SMA Aisiyah I Palembang).

Penentuan level of significance $(\alpha)=0,05$

\section{HASIL DAN PEMBAHASAN}

Suatu butir pernyataan dikatakan valid jika nilai $r_{\text {hitung }}$ yang merupakan nilai dariPearson Correlation> $\mathrm{r}_{\text {tabel }}$ (uji 2 sisi dengan taraf signifikansi 5\%). Perhitungan dilakukan dengan membandingkan nilai $r_{\text {tabel }}$. Dalam hal ini $\mathrm{n}$ adalah jumlah sampel. Pada penelitian ini jumlah sampel $\mathrm{n}=58$ dengan taraf signifikansi 5\% (taraf kepercayaan 95\%) sehingga diperoleh $r_{\text {tabel }}$ sebesar 0,254. Pengujian ini menggunakan bantuan software SPSS 22.0 for windows.

Uji Validitas yang sudah dilakukan menggunakan software SPSS 22.0 for windows pada 58 sampel uji coba instrumen diperoleh hasil bahwa variabel lingkungan keluarga yang terdiri dari 10 pernyataan dinyatakan valid. 10 item tersebut dinyatakan valid karena pernyataan tersebut memiliki Pearson correlation $>r_{\text {tabel}}$, yaitu 0,254.

Suatu variabel dikatakan reliabel jika memberikan nilai Cronbach's Alpha (on standardized Items) > 0,05. Nilai Cronbach 
Alpha untuk masing-masing variabel sudah lebih besar dari 0,05 yaitu Lingkungan Keluarga sebesar ,692, Minat Berwirausaha sebesar 0,862, maka dapat disimpulkan bahwa masing-masing variabel di atas sudah reliabel.

\section{Uji Normalitas Data}

Pengujian ini bertujuan untuk mengetahui apakah data terdistrbusi normal atau tidak. Uji normalitas data yang digunakan dalam penelitian ini yaitu One-Sample KolmogorofSmirnov test dan metode grafik (Probability Plot). Cara untuk mendeteksinya adalah dengan melihat nilai signifikansi residual, jika signifikansi > dari 0,05 maka residual terdistribusi secara normal.

Tabel4 Hasil Uji Normalitas One Sample

Kolmogorov-Smirnov Test

One-Sample Kolmogorov-Smirnov Test

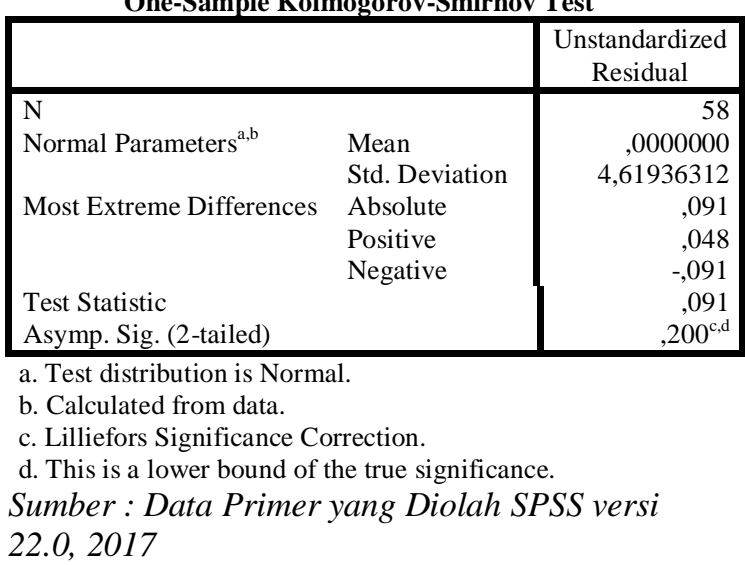

Dari tabel di atas, dapat dilihat bahwa besarnya nilai signifikansi adalah ,200. Hal ini berarti data residual terdistribusi secara normal karena nilai signifikannya $>$ dari 0,05 . Adapun grafik plot terlihat pada 2 sebagai berikut :

\section{Gambar 2}

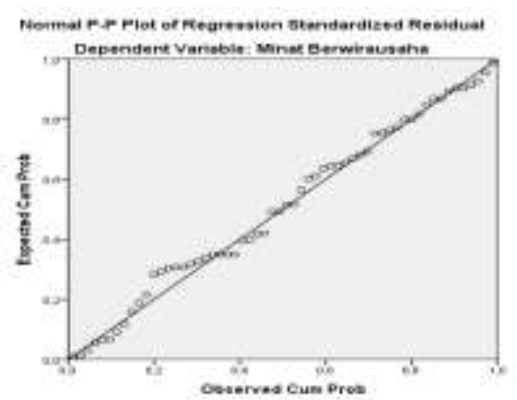

Sumber: Data Primer yang Diolah SPSS versi 22.0,
Berdasarkan gambar di atas, dapat dilihat bahwa titik-titik pada grafik menyebar disekitar garis diagonal dan mengikuti arah garis diagonal pada grafik normal pp plot sehingga data yang digunaka sangat baik dan residual distribusi normal.

Dalam penelitian ini analisis data yang digunakan adalah statistik deskriptif. Analisis deskriptif juga dapat dilakukan pada setiap indikator. Adapun yang dimaksud dengan statistik deskriptif yang dikemukakan oleh Sugiyono (2011:147) bahwa statistik deskriptif merupakan suatu kegiatan untuk menganalisis data dengan cara mendeskripsikan dan menggambarkan data yang telah diperoleh untuk membuat kesimpulan namun tidak berlaku untuk umum.

Dalam penulisan ini dilakukan analisis deskriptif dengan memberikan gambaran data yang mencakup min (nilai terkecil), max (nilai terbesar), dan mean (rata-rata) merupakan poin utama dan standar devisiai (simpangan baku) merupakan ukuran penyebaran.

Tabel 5 Hasil Uji Deskriptif statistik

\begin{tabular}{|c|c|c|c|c|c|}
\hline & N & Min & Max & Mean & $\begin{array}{c}\text { Std } \\
\text { Deviation }\end{array}$ \\
\hline $\begin{array}{c}\text { Lingkungan } \\
\text { Keluarga }\end{array}$ & 58 & 35 & 50 & 41,83 & 3,766 \\
\hline $\begin{array}{c}\text { Minat } \\
\text { Berwirausaha }\end{array}$ & 58 & 45 & 75 & 63,90 & 6,324 \\
\hline $\begin{array}{c}\text { Valid N } \\
\text { (listwise) }\end{array}$ & 58 & & & & \\
\hline
\end{tabular}

Sumber : Data Primer yang Diolah

Berdasarkan hasil perhitungan deskripsi data pada tabel di atas menunjukkan bahwa jumlah valid atau sah untuk diproses adalah sebanyak 58 data. Hasil pengolahan data sesuai pada tabel distribusi frekuensi tentang lingkungan keluarga melalui instrumen sebanyak 10 pernyataan yang diberikan kepada siswa, ternyata hasil menunjukkan bahwa diperoleh nilai terkecil 35 dan nilai terbesar 50, sedangkan rata-ratanya 41,83 dan simpangan baku sebesar 3,766. Variabel minat berwirausaha melalui instrumen sebanyak 15 pernyataan yang diberikan kepada siswa, ternyata hasil menunjukkan bahwa diperoleh nilai terkecil 45 dan nilai terbesar 75, sedangkan rata-ratanya 63,90 dan simpangan baku sebesar 6,324.

Penelitian ini menggunakan analisis regresi linear dengan bantuan SPSS 22.0 for 
windows. Analisis regresi adalah studi bagaimana satu atau lebih dari variabel independen mempengaruhi variabel dependen bertujuan untuk meramalkan dan memperkirakan nilai rata-rata variabel dependen berdasarkan variabel dependen. Hasil analisis regresi diuraikan sebagai berikut.

Tabel 6 Model Summary

\begin{tabular}{|c|c|c|c|c|}
\hline \multicolumn{5}{|c|}{ Model Summary $^{\mathbf{b}}$} \\
\hline Model & $\mathrm{R}$ & $\begin{array}{c}\mathrm{R} \\
\text { Square }\end{array}$ & $\begin{array}{l}\text { Adjusted R } \\
\text { Square }\end{array}$ & $\begin{array}{c}\text { Std. Error of the } \\
\text { Estimate }\end{array}$ \\
\hline 1 &, $683^{a}$ & 466 & 457, & 4,660 \\
\hline
\end{tabular}

a. Predictors: (Constant), Lingkungan Keluarga

b. Dependent Variable: Minat Berwirausaha Sumber : Data Primer yang Diolah SPSS versi 22.0, 2017

Berdasarkan pada tabel model summary di atas menjelaskan besarnya nilai korelasi atau hubungan (R) yaitu 0,683 , ini berarti lingkungan keluarga dan minat berwirausaha mempunyai kaitan yang erat. Dari tabel tersebut diperoleh koefisien determinasi $\left(\mathrm{R}^{2}\right)$ sebesar 0,466 yang berarti pengaruh variabel bebas (lingkungan keluarga) terhadap variabel terikat (minat berwirausaha) adalah $46,6 \%$, dan sisanya $53,4 \%$ dipengaruhi oleh variabel lain yang tidak diteliti dalam penelitian tersebut

Tabel 7. Hasil Persamaan analisis regresi

Coefficients ${ }^{\mathrm{a}}$

\begin{tabular}{|c|c|c|c|c|c|}
\hline \multirow[b]{2}{*}{ Model } & \multicolumn{2}{|c|}{$\begin{array}{l}\text { Unstandardized } \\
\text { Coefficients }\end{array}$} & \multirow{2}{*}{$\begin{array}{c}\text { Standardized } \\
\text { Coefficients } \\
\text { Beta } \\
\end{array}$} & \multirow[b]{2}{*}{$\mathrm{t}$} & \multirow[b]{2}{*}{ Sig. } \\
\hline & $\mathrm{B}$ & $\begin{array}{l}\text { Std. } \\
\text { Error }\end{array}$ & & & \\
\hline $1 \quad$ (Constant) & 15,927 & 6,884 & & 2,314 &, 024 \\
\hline $\begin{array}{l}\text { Lingkungan } \\
\text { Keluarga }\end{array}$ & 1,147 &, 164 & ,683 & 6,996 &, 000 \\
\hline
\end{tabular}

a. Dependent Variable: Minat Berwirausaha

Sumber : Data Primer yang Diolah SPSS versi 22.0, 2017

Persamaan regresi dapat ditulis dengan rumus:

$$
\mathrm{Y}=\mathrm{a}+\mathrm{bXatau} 15.927+1.147 \mathrm{X}
$$

Koefisien b dinamakan koefisien arah regresi dan menyatakan perubahan rata-rata variabel $Y$ untuk setiap perubahan variabel $\mathrm{X}$ sebesar satu satuan. Perubahan ini merupakan pertambahan bila $\mathrm{b}$ bertanda positif dan penurunan bila $b$ bertanda negatif. Sehingga dari persamaan tersebut dapat dituliskan sebagai berikut :

1 Konstanta Sebesar 15.927 menyatakan bahwa jika tidak ada nilai lingkungan keluarga maka nilai minat berwirausaha sebesar 15.927.

2 Koefisien regresi X sebesar 1.147 menyatakan bahwa setiap penambahan 1 nilai lingkungan keluarga, maka nilai minat berwirausaha bertambah sebesar 1.147 .

Uji $t$ digunakan untuk memperlihatkan seberapa jauh pengaruh variabel " $X$ " menjelaskan variabel "Y". Dalam uji $t$ apabila $t_{\text {hitung }}>t$ tabel Ha diterima dan Ho ditolak, nilai $t_{\text {hitung }}<\mathrm{t}$ tabel Ho diterima dan Ha ditolak. Uji t diuraikan pada tabel berikut ini.

Tabel 8 Hasil Uji t dalam analisis regresi

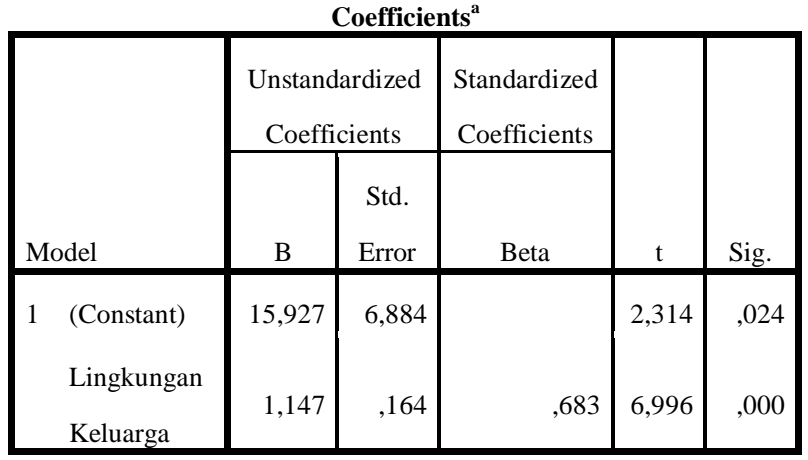

a. Dependent Variable: Minat Berwirausaha

Sumber : Data Primer yang Diolah SPSS versi 22.0, 2017

Berdasarkan tabel coefficients di atas diperoleh nilai t hitung 6,996 , ini berarti bahwa nilai $\mathrm{t}$ hitung 6,996 dengan nilai signifikansi $0,000<0,05$. Maka dapat disimpulkan bahwa Ho ditolak dan $\mathrm{Ha}$ diterima yang artinya terdapat pengaruh signifikan dari lingkungan keluarga terhadap minat berwirausaha.

Berdasarkan uraian di atas dapat diketahui bahwa dari lima indikator lingkungan keluarga dan lima minat berwirausaha yang menjadi tolak ukur peneliti dengan 25 pernyataan, 10 pernyataan untuk lingkungan keluarga dan 15 pernyataan untuk minat berwirausaha serta 58 responden, memperlihatkan bahwa terdapat pengaruh lingkungan keluarga terhadap 
minat berwirausaha siswa Sma Aisyiah 1 Palembang. Dimana setelah diuji hipotesis dengan menggunakan analisis regresi didapatkan nilai hubungan antar variabel lingkungan keluarga dan minat berwirausaha sebesar 0,683. Dan diketahui nilai koefisien determinasi ( $R$ Square $)$ sebesar 0,466 besarnya nilai koefisien determinasi $(R$ Square) 0,466 sama dengan 46,6\%. Angka tersebut mengandung arti bahwa lingkungan keluarga berpengaruh terhadap minat berwirausaha sebesar 46,6\%, sedangkan sisanya dipengaruhi oleh variabel lain.

Hasil penelitian ini sejalan dengan hasil penelitian yang dilakukan oleh Wahyu Nur Cahyani (2016) yang berjudul "Pengaruh Motivasi Dan Lingkungan Keluarga Terhadap Minat Berwirausaha Mahasiswa (Studi Kasus Mahasiswa Angkatan 2012 Prodi Manajemen Dakwah di Fakultas Dakwah dan Komunikasi UIN Sunan Ampel Surabaya). Dalam penelitian yang dilakukan oleh Wahyu Nur Cahyani (2016) menyatakan bahwa Lingkungan Keluarga berpengaruh secara signifikan terhadap minat berwirausaha dengan hasil koefisien sebesar 0,190. Atau 19,0\%. Kemudian hasil penelitian yang dilakukan Deden Setiawan yang berjudul Pengaruh Ekspektasi Pendapatan, Lingkungan Keluarga Dan Pendidikan Kewirausahaan Terhadap Minat Berwirausaha (Studi Kasus Pada Mahasiswa Akuntansi Universitas Negri Yogyakarta). Dalam penelitian yang dilakukan Deden Setiawan menyatakan bahwa terdapat pengaruh lingkungan keluarga terhadap minat berwirausaha mahasiswa akuntansi universitas negeri Yogyakarta, hal ini ditunjukkan oleh nilai $\mathrm{R}^{2}$ sebesar 0,193 atau $19,3 \%$.

Dalam penelitian ini terdapat pengaruh yang signifikan antara lingkungan keluarga terhadap minat berwirausaha siswa kelas XII Sma Aisyiyah 1 Palembang terbukti berdasarkan hasil uji t diperoleh nilai t hitung 6,996 , ini berarti bahwa nilai t hitung 6,996 dengan nilai signifikansi $0,000<0,05$, maka dapat disimpulkan bahwa Ho ditolak dan $\mathrm{Ha}$ diterima yang artinya terdapat pengaruh lingkungan keluarga terhadap minat berwirausaha.

\section{SIMPULAN DAN SARAN Simpulan}

1. Nilai koefisien korelasi sebesar 0,683 artinya menunjukkan hubungan yang kuat dan bersifat positif (searah) antara lingkungan keluarga terhadap minat berwirausaha. Untuk mengetahui seberapa besar pengaruh tersebut dapat dilihat dari nilai koofisien determinasinya sebesar 0,466 atau $46,6 \%$ dan sisanya $53,4 \%$ dipengaruhi oleh variabel lain yang tidak diteliti dalam penelitian ini.

2. Persamaan regresi didapatkan $\mathrm{Y}=15.927$ $+1.147 \mathrm{X}$ yang artinya konstanta sebesar 15.927 menyatakan bahwa jika tidak ada nilai lingkungan keluarga maka nilai minat berwirausaha sebesar 15.927. Koofisien regresi X sebesar 1.147 menyatakan bahwa setiap penambahan satu satuan nilai lingkungan keluarga, maka nilai minat berwirausaha bertambah sebesar 1.147satuan.

3. Uji $t$ nilai $t$ hitung 6,996 dengan nilai signifikansi $0,000<0,05$. Maka dapat disimpulkan bahwa pengaruh signifikan dari lingkungan keluarga terhadap minat berwirausaha.

\section{Saran}

Bagi sekolah SMA Aisyiyah 1 Palembang diharapkan dapat menambah jam pelajaran kewirausahaan diluar dari pada mata pelajaran agar siswa dapat mengerti faktorfaktor apa saja yang membuat suatu usaha itu dapat bertahan lama serta dapat berkembang dan juga dapat menumbuhkan minat berwirausaha siswa.

1. Bagi sekolah SMA Aisyiyah I Palembang di harapkan dapat membuka pemikiran siswa untuk berwirausaha karena dapat membuka lapangan pekerjaan dan menumbuhkan perekonomian Indonesia

2. Bagi sekolah SMA Aisyiyah I Palembang diharapkan dapat memberikan pelatihan kepada siswa tentang cara berwirausaha yang baik, agar siswa terbiasa jika nantinya membuka usahanya.

\section{E. DAFTAR RUJUKAN}

Arief Rahman. 2009. Memahami Pendidikan. Surabaya : Lbm.

Djali. 2008. Psikologi Pendidikan. Jakarta : PT Bumi Aksara. 
Husein Umar. 2014. Metode Penelitian Untuk Skripsi Dan Tesis Bisnis, Edisi Kedua. Jakarta : PT Raja Grafindo Persada.

ISMAil Solihin. 2007. Memahami Business Plen. Jakarta : PT Salemba Empat.

Khairudin. 2008. Sosiologi Keluarga. Yogyakarta : Liberty.

M. Dalyono. 2009. Psikologi Pendidikan Komponen Mkdk. Jakarta : PT Rineka Cipta.

Nugroho J. Setiadi. 2003. Perilaku Konsumen : Perspektif, Kontemporer Pada Motif, Tujuan Dan Kegiatan Konsumen, Edisi Revisi. Jakarta : Prenadamedia Group.

Slameto. 2010. Belajar Dan Faktor-faktor Yang Mempengaruhinya. Jakarta : PT Rineka Cipta.

Sri Lestari. 2012. Psikologi Keluarga : Penanaman Nilai Dan Penanganan Konflik Dalam Keluarga, Edisi Pertama. Jakarta : Prenadamedia Group.

Sugiyono. 2010. Metode Penelitian Pendidikan Pendekatan Kuantitatif, Kualitatif,

Dan R\&D. Bandung : Cv Alfabeta.

Sugiyono. 2011. Statisitik Untuk Penelitian. Bandung : Cv Alfabeta.

Sugiyono. 2013. Metode Penelitian Kombinasai : Mixed Methods. Bandung : Cv Alfabeta.
Sugiyono. 2013. Metode Penelitian Kuantitatif, Kualitatif dan R \& D. Bandung Alfabeta.

Suryana. 2013. Kewirausahaan : Kiat Dan Proses Menuju Sukses, Edisi Keempat. Jakarta : PT Salemba Empat.

Syah. 2007. Psikologi Belajar. Jakarta : PT Bumi Aksara.

Www.coretanberkelas.blogspot.com/2014/02/ pengertian-wirausaha-dankewirausahaan.html?m:1.

Www.Perpuskampus.com/pengertianlingkungan-keluargal. 